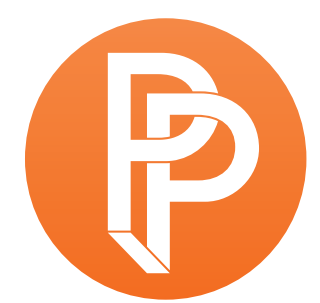

PERFORMANCE

PHILOSOPHY

\title{
CHOREOGRAPHIES OF DISSENT AND THE POLITICS OF PUBLIC SPACE IN STATE-OF-EMERGENCY TURKEY'
}

\author{
SEVIBAYRAKTAR UNIVERSITY OF CALIFORNIA, LOS ANGELES
}

Over the last decade, the consolidation of an authoritarian political system in Turkey, accompanied by neoliberal socio-cultural and economic programs, has set a stage for political unrest in the country. Since 2007, large-scale public assemblies opposing these government policies were gradually repressed through legal, constitutional, and coercive measures. A state of emergency declared following an attempted coup d'état in 2016 restricted even more profoundly the rights of political public gatherings. During this period, the city of Istanbul, the cultural and financial capital of the country, had been the center of a major struggle between urban activists from a variety of grassroots organizations and governing bodies in the city such as the governor, the police, and the state authorities. Activists defending cultural, social, and environmental rights as well as gender equality organized major campaigns and disseminated their political statements among the urban public while reclaiming the right to use public spaces of Istanbul. This article aims to contribute to the documentation and analysis of the dissenting struggle against the increased level of political difficulties since 2016, as well as to show how dissenters innovatively choreograph the urban space and create ephemeral, mobile, and minor scale political assemblies as a mode of resistance which I conceptualize as "tactics of dispersal."

By way of introduction, the 2016 LGBTQI+ Pride Parade was a crucial moment in changing spatial politics of dissent in urban Turkey, encapsulating the contest between the state and protesters and foreshadowing the shifting landscape of grassroots activism. Pride had been celebrated in Istanbul since 2003, yet the twelfth annual march in 2015 was suddenly banned because it coincided with Ramadan, the holy month of fasting for Muslims, both falling in the month of June. Despite 
Governor Vasip Şahin's clampdown, participants gathered on the appointed date in Istanbul's Taksim Square, the symbolic center of left-leaning and other dissenting movements in Turkey, and were violently attacked and dispersed by the police. Citing concerns about security and public order, the Governor declared the 2016 Pride Parade also illegal, which meant, once again, police violence, custody, and torture for the demonstrators. In response, the Istanbul LGBTQI+ Pride Committee released a press statement inviting protesters to "obey the call of the police" and "disperse to every single corner of İstiklal Avenue." The statement reads:

\begin{abstract}
We are announcing, with sadness, that we will not be able to hold the 14th Pride March. But our confidence in ourselves, our horizon, and our dreams are much bigger than a march, İstiklal Avenue, this city, and this country. Our fight for existence goes beyond yesterday, today, and the future because we were here, we are here, and we will be here. [...]

Police forces have told the people attempting to read a press statement during Trans Pride March to voice their legal and political demands: "Please disperse and allow life to go back to its normal course." We are obeying this call: On Sunday, 26 June we will disperse to every single corner of İstiklal Avenue, we are reuniting with each other on every street and avenue in Beyoğlu. Instead of living a life that is imposed on, a life that normalizes violence, oppression, and denial; we are living the life we chose, the life in which we exist with pride and honor and we are "Letting life go back to its 'normal' course" by:
\end{abstract}

DISPERSING, DISPERSING, DISPERSING.

(LGBTI News Turkey, 2016)

As 2016 Pride demonstrators dispersed in Taksim along istiklal Avenue and its side streets, they moved from one place to another, searching out opportunities for interaction, momentary encounters, and rapid departures from police violence. As they had not been able to constitute a central assembly, the queer, trans, and feminist activists performed "dispersal" as an innovative form of assembly-making and a counter-movement against the maneuvers of the police. When they met briefly at a street corner, they read the above statement in public, recorded their action to disseminate on social media, and dispersed once again in the back streets of the main avenue. Since folk dancing has long been a popular form of protest in Turkey, demonstrators also formed folk dance groups during the moments in which they were able to gather in the street. ${ }^{2}$

In the following months, the police continued to regulate activists' bodies through forcefully dividing, segregating, enclosing, and inhibiting their movements. In response to the elevated oppression, dissenting groups further developed alternative ways of dispersing themselves in the city to defy police violence and find new locations to perform and promote political practice. Through their acts of dispersal, dissenters have expanded the space of political action by departing from the greater assembly in order to make smaller scale and moving assemblies at the peripheries of the primary space of activism.

While body politics of public assembly has been widely discussed in relation to recent social movements (Butler 2015; Foellmer 2016; Kedhar 2014; Ruiz 2017) many of these studies shared an 
approach of political gatherings as massive "choreographic arrangements" that "shape and reshape the social, the aesthetic, and the political" (Gerecke and Levin 2018, 5). My focus on dispersal complements and expands on these discussions of assembly by demonstrating how bodies act to maintain the possibility of political interaction even when they depart from the mass choreography of protest and thus continue "constructing physical interference" in the public space (Foster 2003, 412). Dispersal as a choreography is deployed both by the state forces and the activists in Turkey: on the one hand, the police violently block, prevent, scatter, disjoint, clear, and even "disappear" (detain, torture, and kill) dissenting individuals; and on the other hand, dispersal, as a survival tactic, reveals political and kinetic resilience of dissenters who continue moving, circulating, interacting, conjoining, and performing through their temporary and immediate encounters in the urban space. I suggest that this flexibility, and also ambiguity, of dispersal provides potentials for collective political agency.

In this article, I apply Hannah Arendt's analysis of the mobilization of violence, used by totalitarian states to individualize and atomize their citizens and prevent them from coming together in public assemblies, to the present situation in Turkey and discuss the framework that I call "tactics of dispersal," a set of choreographic practices of dissenters to enable political action at moments of extreme coercion. Scholars inspired by Arendtian political theory, such as Judith Butler and André Lepecki, have focused on the possibilities of assembly as a form of embodied agency to undertake progressive politics. Here, I will discuss what happens when bodies are not able to assemble in the public sphere due to police terror. I am interested in the "choreopolitics" of dispersal (Lepecki 2013): persistent choreographies which mobilize the public for social change against the hegemonic means of bodily control and political order. My theory of dispersal contributes to the emergent body of work on choreographies of assembly as it updates and nuances the idea of what assembly is and can be and how it works choreographically under current social and political developments consolidating authoritarian governments in Turkey and beyond.

I present a conceptual framework of tactics of dispersal on the basis of my fieldwork, which draws on numerous interviews I conducted with participants of protests in Istanbul between November 2016 and October 2017, such as those who joined feminist and LGBTQI+ demonstrations, antiemergency decree protests, environmental movements, and urban grassroots activist efforts. These interviews were mainly conducted with dissenters who self-identify as women from various political, ethnic, and class backgrounds. Despite their different, and often conflicting, political agendas, they all oppose the authoritarian state regime and its establishment with legal and forcible implementations. With these examples, I discuss the dispersal choreography of the police that sought to "isolate" and individualize dissenters and the ways that activists disperse in the city in order to carve out the public space for their political aims. I analyze various iterations of dispersal and argue that demonstrators tactically use and subvert the police strategy of dispersal to mobilize peripheral urban spaces and create ephemeral gatherings in times of political crisis.

In the following pages, I will introduce the concept of dispersal by looking at its multiple modes and manifestations in the city. First, I will explore recent re-configurations of the public space under authoritarian policies, and explore how dissenting citizens were exiled from the principle public 
square of left-wing activism in Istanbul with brutal applications of dispersal. Then, I will investigate how dispersal becomes a potentially transformative mode of political engagement through counter-maneuvers of dissenters who scatter throughout the city. Finally, I will examine protesters' folk dance gatherings to discuss how they claim the public space through the transience of dance. Building on Arendtian political theory, my analyses will show that tactical deployments of dispersal (in both urban and bodily scales) enable demonstrators to convert the police choreography into political action during which they experiment with the ideas of plurality, inclusivity, and perseverance.

\section{Exile from Taksim Square, the Iconic Center of Political Activism}

A brief historical discussion about the urban space politics of the grassroots movements in Turkey is significant to understand how dissenters have been exiled from the main square of political activism in Istanbul and dispersed in the city. The Ottoman Empire, preceding the Turkish Republic inaugurated in 1923, invested in constituting its capital city of Istanbul as the model of the empire's social and political values. Beginning in the second half of the nineteenth century, today's Taksim area, formerly named Pera, has been the center of overtly secular and "modern" lifestyles with its public parks, street lights, and tramways as well as theaters and other entertainment venues. After the establishment of the Turkish Republic, this area continued to be an important social and financial center for the city. Pietro Canonica, a prominent Italian artist, crafted the Republic Monument in 1928 to provide Taksim Square with its "national" characteristics. The monument depicts Mustafa Kemal, the founder of the republic, as a soldier on one façade and as a teacher in modern clothes on the other, signaling the core values of the emergent Turkish nation after the first World War.

The monument marked the square as the center of public national ceremonies in the early twentieth century. In the 1930s, state officials initiated a popular ceremony where denizens of Istanbul would pay tribute to the Republic Monument with a wreath (Batuman 2015, 10). In the 1940s and 50s, civil demonstrators with nationalist sentiments also chose Taksim to stage their protests against non-Muslim minorities living in this area, mainly Christian Greek and Armenian citizens of Turkey. Demonstrations that began at the Republic Monument usually moved down along istiklal Street, which has continued to be the major trajectory for protests until today. In the 1960s, left-wing grassroots groups and students' movements became more visible than right-wing agitation in Taksim Square. Students' demonstrations often started in Beyazıt Square in the historical peninsula, a location close to the Istanbul University, and continued with more participation as they marched to Taksim Square (10-11).

A significant incident that made the square an iconic space of left-leaning dissenting activism took place on May Day of 1977. On that day, large groups of protesters, including students' organizations, workers' unions, and political parties, converged on Taksim from different directions and gathered around the monument. Gunfire from an unknown source suddenly dispersed the crowd, and as a result, thirty-four people died and hundreds were injured. Two years later, May Day celebration was banned from Taksim, and it remained forbidden for the next three decades. 
Protesters persistently challenged the ban in the following years by trying to reach the square despite the accelerating police compulsion. Representing a power contestation between the police and protesters, Taksim Square has become the symbolic center of left-leaning activism in Turkey.

In 2013, another crucial shift in the urban political history of dissent occurred in Taksim Square. A small group of demonstrators occupied Taksim-Gezi Park, a recreational area adjacent to the square, to stop bulldozers from razing the green area. The occupation began in opposition to the government's commercial transformation plans targeting historical sites and public parks. ${ }^{3}$ The demolition was part of a government redevelopment initiation that included construction of a shopping mall and a luxury residence through re-constructing the Ottoman Artillery Barracks, demolished in 1931. Protesters decried the lack of transparency about plans for the area's redevelopment. Riot police forcefully dispersed those gathered in the park, which brought more people to defend the place and converted the environmental resistance into a nationwide political mobilization for social justice in Turkey. ${ }^{4}$

The 2013 Taksim-Gezi Park movement ended when the police stormed the park and evacuated it. Since then, the Republic Monument has been usually closed off to activist gatherings and isolated by police barricades. Any attempt at political demonstration in the square and the adjacent istiklal Street has been banned and met with serious police attack. In addition to spatial enclosure of Taksim, a series of ISIS attacks and the state's insufficient effort to prevent fatalities (2015-2016) rendered mass demonstrations and political gatherings nearly impossible in Istanbul. Following an attempted coup d'état in July 2016, the right to public assembly for anti-government demonstrations was officially prohibited by the declaration of a state of emergency, which was extended in regular intervals for two years until July 2018. During this time, many state-ofemergency decrees were instituted not only targeting perpetrators of the coup, but also causing over 100,000 anti-government and dissenting teachers, academics, and public service employees to be dismissed from their jobs or to suffer false accusations (Human Rights Watch 2018; Hürriyet Daily News 2018b; Pişkin 2018). The decrees legalized arbitrary dismissals, arrests, and killings of the associates of all oppositional groups, including scholars, students, journalists, human rights defenders, and members of parliament-notably MPs of the pro-Kurdish Peoples' Democratic Party (HDP). By mobilizing nationalist and pro-state mass movements within a polarized society, creating the conditions for exile and deportation of dissenters, and imprisoning members of civil society, state authorities created an atmosphere of permanent danger and instability.

This process of normalization and legalization of violence and fatalities under the conditions of Turkey's state of emergency exemplifies Giorgio Agamben's concept of a state of exception, "a space without law" or "a zone of anomie" $(2005,50-51)$ that Agamben defines as a "temporary suspension of the rule of law on the basis of a factual state of danger" (96). While the Foucauldian notion of biopolitics refers to the management and distribution of life as a fundamental technology of power of liberal states (Foucault 2007), Agamben sees the basis of power in a politics of death, what he calls "thanatopolitics." He argues that the sovereign state enters into intimate fields of life through its institutional experts such as the doctor, the priest, and the scientist, who altogether serve to convert biopolitics into thanatopolitics in which the sovereign establishes authoritative 
social and political order by giving death $(1998,72)$. This form of power produces "bare life," located at the margins of the political order, and a body that is therefore killable since it is deprived of political rights and the protection of law (Agamben 1998, 52). When the state of exception expands without limits and becomes the rule itself, "bare life" coincides with the political realm, and any form of state violence is considered legitimate.

Building on the state's self-attained right to kill individuals in Agamben's theory, Achille Mbembe (2003) elucidates how modern states operate through spatial segregation and mass killings of populations. His notions of "necropower" and "necropolitics" question how some populations are considered "killable" because of their race or ethnicity, construed as an essential biological or cultural difference. Mbembe's concept of power resonates with Judith Butler's theory of "grievability" (2009), investigating how some bodies are produced in the era of the war-on-terror as "disposable" when their lives are not counted as mournable and grievable. Butler argues that violence operates through certain bodies iteratively, and in each iteration, it increasingly becomes the normative condition for marginalized bodies, whose lives do not register as having value, and are therefore at risk of disease, poverty, starvation, displacement, and exposure to arbitrary state violence (26). These theories speak to the hegemonic performance of dispersal through which the Turkish state enacts politics of terror and a vulgar exhibition of its power. A predominant choreography of dispersal manifests the way the state commands centralizing authority and can drive out its opponents, showing them to be on the run, in fear, cowering, always as potential detainees and murder targets. It aids in the creation of an atmosphere of repression through the display of pure authority and occupation of public space by state agencies like the police or the military.

An oppressive environment can be maintained largely through the reproduction of abiding feara strategy which Hannah Arendt analyzes in The Origins of Totalitarianism ([1958] 1966), where she argues that the creation of despair is a requirement for totalitarian regimes. A totalitarian rule is supported by the mobilization of terror by governing forces, arbitrary arrests, a secret police presence, and control of everyday life. Arendt analyzes the ways in which ruling powers use police coercion to destabilize all other institutions in society and spread the condition of mass atomization and isolation upon which the totalitarian movement thrives (323). Arendt defines isolation as "a loss of stable social relationships, loss of common sense. It is the desperately disorienting one of losing the company of even one's own solidarity thoughts" (474). Since they are forcibly disconnected, individuals under totalitarian rule lose the potential for political engagement and efficacy.

For Arendt, atomized individuals would be powerless because they cannot move and interact to create the necessary conditions for political action. Similarly in Turkey, the new legal prohibitions of the state-of-emergency decrees, as well as terror attacks and police violence, dispersed activists whenever they attempted to gather in order to form central public assemblies. But conversely, in their efforts to themselves deploy dispersal as a tactical response, demonstrators show the possibility of transforming oppressive conditions of isolation into emancipating forms of political action. As I will discuss, such a tactical approach to mobility is inherent in the acts of dispersal that 
enable activists to perform their agency and convert potential violence into a relational practice of politics.

My interviews with activists were conducted during the state of emergency in Turkey, and thus they reflect dissenters' resilience and creativity under the difficult conditions of this period. Such uncertainties in the protest space and a constant struggle between the possibility and impossibility of performing demonstration made improvisation a necessary tool for both the street activists and myself as a researcher, and I usually met my interlocutors randomly at protest sites. When I talked to protesters, some of them suggested to meet later to enable us to have longer conversations; others wanted to talk on the spot, and we went to a nearby teahouse from where we could see the demonstration area and go back there when needed; some activists invited me to other political meetings before or after giving an interview so that I could be involved in grassroots politics in other spheres as well. All these different performances meant that the research practice was dynamically engaged with the conditions of the street and open for immediate changes and surprises.

On the day of a planned political meeting in Taksim Square, I went to meet Ayla, ${ }^{5}$ an environmental and urban justice activist. The tensions were already high in istiklal Avenue as many armed police vehicles were waiting in the area with their engines on, ready for action. Police barricades closed each street along the two-mile long avenue. During the 2013 Taksim Gezi-Park resistance, the backstreets of istiklal had become home to many activists, who had carefully studied its blind corners, narrow openings through nineteenth-century European passages, and tricky culs-de-sac, and sussed out both friendly and hostile merchants. When I met Ayla, she was angry:

\section{It feels meaningless to demonstrate or march along istiklal Avenue, because we are trapped here. They trapped us here, leaving no room to escape. You are all surrounded, and they are here to kill you. So why do you go out and walk on this street like a cage? I don't think there is a point unless you want to be killed. I don't feel excited anymore to march along istiklal. (Istanbul, 26 April 2017)}

The square and the main street were completely closed off, leaving no room for any attempt at political gathering in the area. In other instances, a central square may be permitted yet enclosed and isolated from the rest of the urban inhabitants by police barricades, which signify potential danger and emergency. In one interview, Zerrin, a social justice activist, mentioned the rally run by the pro-Kurdish HDP before the presidential referendum in April 2017. The referendum was about a constitutional change from parliamentarian to presidential system in Turkey. The rally called "El Ele" ("Hand in Hand") was located in the large Barbaros Square, next to a busy pier in the Beşiktaş neighborhood where boats run between the Asian and European sides of the city. The area was spatially isolated with the installation of police equipment. Zerrin went to the meeting, but instead of going inside the square, she watched it from outside the cordoned-off area:

I walked all around [the barricaded square]; there was one gate and ten police officers [at the gate]. I did not enter; it was like a cage. I was not afraid, but I felt truly sad. It was painful; I did not want to be there. (Istanbul, 19 April 2017) 
An enclosed, divided, and controlled space resembled a "cage" for both Ayla and Zerrin. The increased militarization of everyday life and the strong visibility of the police in Istanbul have contributed further to the precariousness of activists in public spaces: armed police vehicles called akrep ("scorpion") rolling through the city; soldiers wearing balaclava snow masks and carrying rifles as they walk in İstiklal Avenue; and check-points in frequently changing locations, where the police ask passersby for their identity documents for a background check, known as GBT-kontrol (control for "general knowledge gathering") indicated multiple forms of hegemonic choreographies of control. In addition, ongoing urban gentrification projects in Taksim dramatically increased property prices in the area. Regulations against the proliferation of cultural centers, entertainment venues, restaurants, and bars changed the social and demographic structure of Taksim. As a result of these developments, many dissenting groups, particularly feminist and LGBTQI+ communities, who had experienced severe political, cultural, and economic limitations, were exiled from the iconic Taksim Square and found alternative locations to continue their activities.

As activists find ways of struggling under changing political and spatial circumstances, authorities also study protesters' movements and look for new routes, intersections, and streets to block, enclose, and evacuate. As an example, the Istanbul Municipality has designated certain locations for the performance of dissenting political demonstrations. This serves almost to quarantine dissenting groups from the larger public, so that they would not "contaminate" the public sphere with their political ideas. In 2015, the Istanbul Governor's Office allowed the May Day celebration only in an outdoor parking lot in Beylikdüzü, two hours away from Taksim Square by public transportation (Diken 2015). In 2018, the Governor's Office issued a list of nine sites eligible for grassroots political rallies, which once again did not include Taksim Square (Hürriyet Daily News 2018a). These approved areas of protest were not only located far from the city center, but also mostly constructed through projects of land reclamation and urban gentrification, causing the dislocation and impoverishment of ethnically, racially, and economically marginalized communities in those areas. Designating these "remote" areas as sites of demonstration was paramount to inviting anti-government protesters to act as accomplices of the plans of dispossession. Dissenters have responded to these efforts of enclosure and segregation by claiming peripheral urban areas attuned to daily life and exploring other locations to maintain their political intervention.

\section{Tactics of Dispersal: Resistive Choreographies of Dissent}

How can we explore political agency in a scattered public space where bodies are unable to gather and cannot freely manifest their democratic rights in means of action? How do we contextualize collective political agency when assembling is almost impossible in an environment of compulsion and violence? How do activists negotiate dispersal, as an oppressive and totalizing maneuver of the state, through their bodily interaction? How do they expand the space of the political beyond iconic streets and squares of activism? In response to the autocratic form of dispersal practiced by the state, I want to focus on two tactical forms of dispersal: dispersing in the city to politicize its relatively peripheral areas located off the main square, and dispersing through the ephemerality 
of folk dance. In both cases, activists disperse in order to maintain the potential for making political assemblies.

In her study on theatricality and resistance in the cities of Belgrade, Sarajevo, and Toronto during and after the Balkan wars in the 1990s, Silvija Jestrović demonstrates that spatial exclusion and marginalization create exilic spaces in different urban contexts. The consequence of living in a state of war nourished by an oppressive and violent nationalist regime resulted in the establishment of "inner exilic spaces-their city-within-the-city-to preserve and protect a form of urban life that had been threatened" $(2013,191)$. Jestrović's framework is relevant here as Istanbul has become an "exilic city" for its dissenting inhabitants in the years following the 2013 Taksim-Gezi Park resistance. Urban dissenters created "inner exilic spaces" by moving from Taksim to other neighborhoods, such as Kadıköy, Beşiktaş, and Bakırköy, which are governed by the liberal municipalities of the Republican People's Party (CHP), the main opposition of the ruling Justice and Development Party (AKP) government. Activists politicized inner exilic spaces within these relatively peripheral neighborhoods by persevering in the performance of sit-ins, vigils, press declarations, marching protests, and folk dance to show their opposition to the authoritarian rules and policies. They also revealed hidden histories in these new locations, layered like a palimpsest, by drawing attention to the erasure of diverse urban landscapes.

For example, Betül Celep protested her dismissal from her job as a result of a recent state-ofemergency decree by performing a vigil in one of the busiest pedestrian intersections of Kadıköy neighborhood, located in the Asian side of Istanbul. She left home every morning as if she was going to work as usual and performed a sit-in protest until late hours. Her vigil in Kalkhedon Square continued for 66 days between January 23 and March 29, 2017, during which Betül converted an everyday marketplace into a space of resistance and made her unjust discharge visible to others (KHKadınname 2017). Instead of the well-known Taksim Square, she picked this small pedestrian intersection, which was unknown to me until her action. In fact, I could not find any square by this name in city maps. Finally, a black-and-white photograph from the early 1900 s proved that this was a market square of the Greek Orthodox Church Aya Efemiya. Through Betül's action, the old church square, which is otherwise unnoticed, is included in the social memory of dissent, as other progressive movements have also begun to utilize the square. For example, dissenting women from several grassroots organizations joined a campaign that promoted a "no" vote in the referendum on the establishment of a presidential system. Their campaign entitled "Hayır Diyen Kadınlar" ("Women Who Say No") held a demonstration in February 2017. Women met in a central street in front of the Süreyya Opera House in Kadıköy and marched along pedestrian streets where bars, cafes, and restaurants were located. When they arrived at Kalkhedon Square, they performed a press declaration and a small group of women folk-danced next to the police. Although dissenters dispersed in the city, they hence continued inspiring each other and building alternative public spaces of grassroots politics by interacting and engaging with past and present social movements that used in those spaces.

Protesters and the police continuously act to decipher and challenge each other's movements to use "dispersal" more effectively: while the police explore ways to deactivate and defuse, activists 
seek to evade police violence through scattering in the public space, enabling further action. I suggest that these kinesthetic negotiations between state forces and activists participate in Hannah Arendt's notions of "isolation" and "politics." As I mentioned earlier, in Arendt's formulation, totalitarian power aims to disconnect people through the use of violence, yet the activists in Istanbul maintain the conditions of their interaction by performing a nuanced choreography of departure, which inventively keeps bodies connected in the public sphere. They thus enact what Arendt defines as the "productive potentials of isolation" ([1958] 1966, 478) through unrevealing the relational nature of dispersal movement which is also its political capacity.

In The Human Condition ([1958] 1998), Arendt explores the conditions of possibility for political experience and conceptualizes a "politics" that is based on "action," the act of beginnings (177), occurring between individuals who "live on the earth and inhabit the world" (7). To "act" is to set something in motion and start something new which cannot have been experienced before. This unexpectedness and genuine novelty are unique qualities of human action as a worldly practice. For Arendt, through our intercourse with others we communicate diverse political experiences and develop ever-changing possibilities of interaction. Since "each human can act and start something new" (viii), each interaction must be different. Such unanticipated contingency and distinctiveness of human action corresponds to "plurality" as the primary condition of (political) life. Arendt defines plurality as "living as a distinct and unique being among equals" (178). In a plural society, each member equally tries to persuade others through speech and action (26). So that plurality is realized through interpersonal exchange, coexistence, and association of a multiplicity of diverse political practices in the public realm.

Therefore, while Arendt's notion of isolation is a fertile ground for totalitarianism and also its ultimate result, the power of plurality is activated through grassroots politics valuing intersubjective action. Referring to political theorist Edmund Burke, Arendt conceptualizes power as the interaction of those who are "acting in concert" ([1958] 1966, 474). She suggests that totalitarian states aim to abolish freedom of movement and inhibit people from initiating new networks, yet individuals continue interacting in alternative and creative ways to resist the isolating power and to establish plurality. Arendt highlights the necessity of praxis, of collective action, against the devastating impacts of those dividing, isolating, and encapsulating power of hegemony. Moreover, because politics is not given or inscribed into bodies but a product of specific histories and of historically changing conditions, collective political action is relentlessly re-learned, mentored, practiced, and rehearsed through interpersonal exchange and experience.

The social and political potential of the Arendtian notions of politics and action have been a concern of not only political scientists but also performance and dance studies scholars. Among those include Judith Butler, who highlights the goal of concerted actions and unpredictable alliances of bodies in public spaces as she explores agency in relation to the idea of public assembly. In her conversations with Athena Athanasiou, Butler builds on the Arendtian concept of action as human existence and experience, and argues that through moving together and performing assemblies, dissenters claim recognition by "being there," or appearing in public space. Butler suggests that their presence and amalgamation mean "we are still here," or, "we haven't yet 
been disposed of. We haven't slipped quietly into the shadows of public life" (Athanasiou and Butler $2013,196)$. When people are assembled in the street, Butler sees them claiming a bodily existence as a statement of plural, interdependent, and relational politics. Judith Butler offers a performative theory of assembly through which one can examine the resilience of precarious bodies when they act together in interdependent ways. Precariousness paves the way for mutual dependency; it is an act of reciprocity that establishes a sense of "we" for sustained and sustainable political relations (Butler 2009, 14). Interdependency delineates a constellation of individuals who are profoundly responsive to each other; it is a "social network of hands that seeks to minimize the unlivability of lives" (Butler 2015, 67).

Dance theorist André Lepecki (2013) also offers a look at the Arendtian notion of politics in relation to human movement and shows the possibilities of exploring these concepts fruitfully in dance studies. Applying Arendt's ideas of intersubjective relationality and moving together as a way to create novel forms of political action, Lepecki examines the relationship between the political and the kinetic. He argues that dancing bodies move together in a search for alternative configurations against the controlling mechanisms of power. Choreography creates particular trajectories for bodies through the experience and practice of movement as freedom, which he calls "choreopolitics." These choreographies are resistive because they invent, activate, seek, and experiment with action to exercise emancipating possibilities $(2013,20)$. In contrast, Lepecki's concept of "choreopolicing" refers to the restrictive and oppressive force of the state and police control in two ways: As a theoretical concept, the police "choreographs" (19) by determining "the space of circulation for protesters" (16), which demobilizes political action because it does not allow activists to initiate their own movement. As agents of control, cops secure such circulation by imposing blockades, channeling demonstrators, dispersing crowds, and lifting up and dragging bodies around, and thereby exercise choreographic command of the protesters' bodies (15-16).

Lepecki theorizes choreopolitics and choreopolicing as binary categories in which restrictive and controlling acts are found in opposition to emancipatory performances of those who always find ways of moving. As an overarching concept, choreopolicing is about preventing activists from moving together through commanding a forceful and continuous circulation in space. In Turkey under current political developments, however, choreopolicing refers to a thanatopolitical strategy of power that operates through not only circulation but also, and specifically, exclusion and elimination. Nevertheless, similar to other stagings of power, it is far from being monolithic and immutable. As dissenters in Istanbul alter the police choreography by tactically dispersing themselves, they gather together in smaller assemblies with ever-changing combinations of bodies. In this vein, dispersal in recent political protests appears as a relational as well as subversive choreography through which the protesters interact with the police, even as they interact with each other, to transform hegemonic violence into political potentials for resistance. Although dispersal mobilizes fear and serves the isolating violence enacted by the state and its police technologies, a tactical repurposing of the choreography manifests an aim for collective action derived from activists' distinct political practices and efforts for relationality, highlighting the valence of the Arendtian notion of "politics." 
When urban activists from left-wing, feminist, LGBTQI+, environmentalist, and other dissenting groups deploy dispersal, they make use of the transformative capacity of choreography and tactically resist the strategic maneuvers of the state apparatus. Here I am drawing on Michel de Certeau's (1984) distinction of the "tactics" of ordinary people from governing "strategies" that often take the forms of totalizing discourses and meta-narratives. De Certeau argues that strategies are architectural, based on place, and thus related to the oversight of property; but tactics are articulated in the details of everyday conduct; they are resistive, quotidian, temporary practices of the body, a system of "microbe-like operations proliferating within technocratic structures and deflecting their functioning" (30). Tactics are related to uses of time more than space since "the space of a tactic is the space of the other" (37). Hence, tactics are transient and necessitate mobility; unlike strategies, a tactical space "cannot keep what it wins" (37), in which sense it can never possess property; but it will always be "poaching on the property of others" (xii). De Certeau conceptualizes a tactic as an "art of the weak" (37); it is also a bricolage through which the artist bravely juxtaposes diverse elements at hand in order to provide a known phenomenon with a fresh perspective. Therefore, fixing bodies in space may enable their identification and subsequent targeting, but constantly circulating, unfixed bodies escape the state's radar and defy it. Dispersal, as a tactical move, an aesthetic political intervention of dissent, requires a constant occupation of the space of the other. It renders bodies relational at the moment of their departure from the collective body, and makes possible ad hoc and hit-and-run types of assembly under the precarious conditions of the street.

\section{Folk Dance and Choreopolitics of Dispersal}

Shifting from the scale of the city to that of individual bodies, another tactical use of dispersal is deployed through the activist appropriation of forms of folk dance. From the 1930s to the 1970s, Turkish state institutions collected, codified, and regulated folk dances. The state elites repurposed non-Muslim and non-Turkish minority dances as part of a corpus of traditions echoing a Turkish culture and history. When regional folk dances were nationalized, all existing or perceived nonTurkish elements in their repertoires (non-Turkish names, narratives, costumes, and props) were replaced with their "Turkish" counterparts. "Turkification" in language resulted in the change of non-Turkish dance names into Turkish ones, although their corresponded meanings were not necessarily preserved. These nationalist endeavors resulted in the standardization of particular folk dance choreographies as representatives of their respective genres. While some choreographies became part of the state repertoire and taught at institutions, such as public universities and folk dance associations, others have been peripheralized or excluded from the repertoire.

Since the 1990s, demonstrators have employed these suppressed dances, such as styles of halay and horon, as a form of opposition to the disciplining and controlling implementations of the nation-state. In contemporary protests, both genres are popularly used by groups of people in different sizes: halay is a Turkish genre name of Kurdish circle dances, which is typically called govend (dance) in Kurdish. As a heritage tradition of Kurds in eastern and southeastern regions of 
Turkey, govend was marginalized in the 1980s and became a political symbol of the Kurdish struggle for cultural recognition in Turkey during the 1990s. Horon, on the other hand, has been considered a national dance representing a supposedly homogeneous culture and history of the Black Sea region, in northeastern Turkey. In fact, several ethnic communities were (and partially still are) living next to each other in the region including Pontian Greeks, the Hemşin, the Laz, Georgians, and Turks. Although they all perform horon with differences in style and execution, only one horon sequence, choreographed in the 1970s, is considered the national form.

Activists manipulate and transform the institutionalized choreographies by merging them with other folk dances, conglomerating their various stylings, using an ordinary movement vocabulary at moments of high tension, and engaging with a politics of emotions so that their dance demonstrates anger, mourning, and lament as well as joy against faces of power. In this tactic, protesters perform folk dance aligning their bodies in circles, semi-circles, and lines. Each dance group has a leader who improvises and guides others throughout movement sequences. In protests, the role of the leader becomes a temporary position that anyone can claim during the dance. Demonstrators usually convert traditional accessories of folk dances, such as handkerchiefs, into political signs such as banners; they may individually interpret and execute movements in rhythmic harmony with others; and they may freely enter and exit the dance. Many of these qualities are typically considered inappropriate in institutional and traditional iterations of folk dance. To "join in" the group, participants proactively hold hands with others, yet also consider those who may want to dance next to their comrades or only among women or men. When a dancer leaves the group, they step back gently to make sure that the (semi)circle or line form is not broken due to their absence. If the dance is terminated by a collective action, then protesters briefly clap and chant political slogans as a way of declaring the end of the event, and often disperse in different directions. Folk dance groups enable activists to rehearse alternative, enduring, and persistent choreographies of dispersal and also render temporal and smaller size assemblies possible since they can be performed for a few minutes and with a handful of people. The ways in which protesters unite, depart from, and position themselves in the dance also implies how they negotiate moving together, innovate political action, and contest power.

Dissenters discuss and negotiate the Arendtian concept of politics through a "choreopolitics" of dance that relies on several choreographic conditions which make moving together possible. Among those, below I discuss two components of folk dance as protest event: "temporality" that is necessary to explore when activists join in and exit from the dance, and "positionality" that provides information about how activists create a relational space during the dance. My examples analyze how dissenters develop ways of participation in the urban public sphere by differentially locating themselves among other bodies, learning steps from one another, and initiating acts of moving together. I focus here not on professional dancers but mostly non-professional dancer-activists who may or may not have previous dance training. Some demonstrators dance only in protest events, yet they commit to deploying folk dance through a persistent practice of learning, mentoring, and repeating during years of participating in political activism. Thereby danceractivists own the authority of performance and dedicate themselves to execute the choreography despite spatial inhibition and police oppression. I engage with diverse dancer-activists' experiences 
and voices in order to address how "choreopolitics" is enacted at a grassroots level to promote plural politics in the Turkish context.

With regard to temporality, folk dances are often spontaneously organized at the moment of demonstration: protesters initiate a dance group within a few minutes, convey their political message and demands, and disperse so as not to be captured. Activists usually perform for as long as they can and depart from the dance circle or line when the police intervene. Suzi, an activist in the Kurdish cultural rights movement and the labor movement, says that when she feels comfortable about the footwork, she joins the dance and keeps going "until the end," without specifying when a dance ends in a protest (Istanbul, 4 April 2017). Like Suzi, Ayla also prefers to stay as long as she can, saying, "I do not leave the dance until the music is over and the group is dispersed... even if I feel short of breath, I do not leave because I do not want to give up the energy that I share with other dancing people" (Istanbul, 26 April 2017). Similarly, Eylem, from a left-wing revolutionary group, is unwilling to leave before the dance is over because she does not want to disrupt the order of the dancing bodies. While she can freely enter and exit the dance, she finds line formations more difficult to leave because the line alignment would expose her absence if she left the dance. She stays in the choreography to show respect to others because her abrupt departure may cause confusion among her comrades and even "ruin" the dance (Istanbul, 6 April 2017). Folk dancing requires a profound consideration of how one's actions would influence the others in a collective movement and thus supports interdependency.

Although the dance may end within a few short minutes, activists repeat the choreography each time they gather during protests and continuously establish spaces for interaction among each other. During her vigil in Kalkhedon Square, Betül Celep performed folk dance many times together with those who came to support her. She emphasizes the importance of getting together with strangers in these protest dance gatherings, saying,

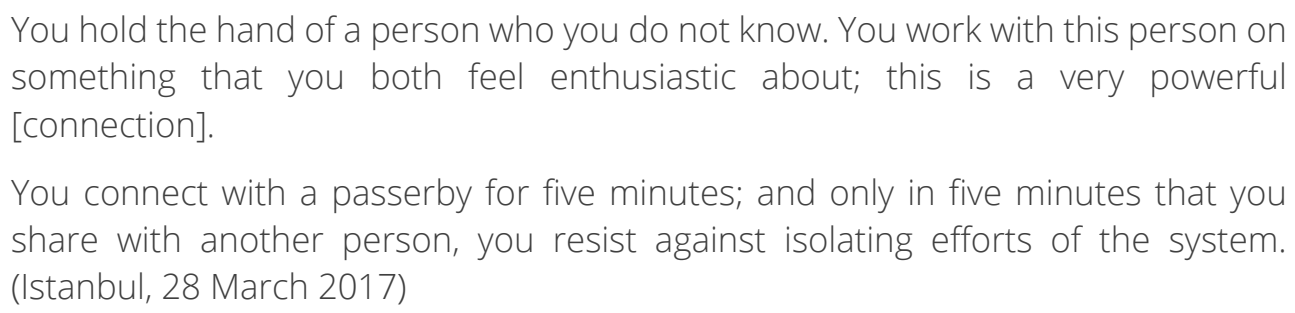

A brief meeting that occurs during the dance has the potential to create change in a larger collective because dancers test the possibility of cooperation among each other through their interaction, negotiation, struggle, and support. The ephemerality of choreography allows dissenters not only to maneuver against forces of "immobility" and control, but also to relate to each other in ways that are always new, enabling them to mobilize the public while disorienting the police. In each gathering, activists redistribute, reinvent, and realign themselves in relation to others and against potential implications of police choreography, reclaiming controlled spaces through their kinetic knowledge. Instead of obeying commands of the police, activist-dancers perform agency by staying 
in the choreography "until the end." They thus affirm political potentials of the dance through their persistent circulations against the isolating and individuating power of hegemonic dispersal.

With regard to positionality, dissenters not only maintain the intersubjective space by performing the choreography, but they also thoughtfully position themselves in the dance. For example, some demonstrators specifically perform next to an expert dancer to learn step patterns accurately, while others prefer not to hold hands with a neophyte dancer in favor of having greater enjoyment in the dance. Choosing with whom to dance and whether to perform a leader or follower position requires decision-making that is imbricated with other social, cultural, and political circumstances. Each time they dance in a demonstration, activists potentially gain more experience to navigate in the dance group. Negotiating positionality in folk dance collectives also helps protesters discuss discrepancies among allying groups. For instance, Keskesor, a Kurdish LGBTQI+ organization, conducted a Kurdish dance workshop in Maçka Park in Istanbul's Beşiktaş neighborhood during the week of the Pride Parade in June 2017. Following the workshop, an instructor told me that these dances promote diversity and equality because one has to hold hands with the next person "even if" this person is a "transwoman, an Arab refugee, or a gay man" (Alex, Istanbul, 25 June 2017). By using dance, the group encourages participants to challenge themselves to move together, and hence live together, with queer and trans individuals as well as migrants, sex workers, and other marginalized subjects in society. In our conversations, Keskesor activists underlined the uniqueness of a queer political practice in contrast to the heteronormativity that they see as embedded in the acts of many in left-leaning groups, who are often afraid of being considered gay when they hold hands with a queer/trans person during the folk dance.

While some people avoid dancing next to a marginalized person, others may have other criteria to position themselves within a folk dancing group. Lara, an environmental activist, indicates that she often joins the dance from the middle of the group because she feels more comfortable surrounded by other people; even though she takes a wrong step, she can adjust her rhythm to others (Istanbul, 3 April 2017). Melek, an activist affiliated with the women's movement and the labor movement, however, prefers to lead the dance because she is a competent dancer. She hopes that by taking the lead, diverse participants would enable to focus on and express a variety of emotions because, as she says, "Dance is an individual expression and you do not have to belong any political group to dance in a protest" (Istanbul, 22 March 2017). Similarly, Esma, a social justice activist, emphasizes: "When I dance in protests, I feel I am not alone; the people on whom I lean my hand, my arm, and my shoulder give me courage" (Istanbul, 13 April 2017). Dance in protest facilitates connection with another vulnerable person in the public space and creates a sense of belonging to a political community while allowing forms of communication among ethnically, racially, economically, and sexually peripheralized individuals. Each time they disperse to meet up in another dance group, dissenters re-evaluate their capacities and ways of moving together with surrounding bodies. The forms of departure from a folk dance collective provide them with information about how to engage and collaborate with other bodies.

Vulnerable bodies stand next to one another in a precarious public space and perform agency without necessarily synchronizing their motions or applying fixed movement patterns but initiating 
novel ways of acting together. This inventiveness at the moment of departure from a folk dance community provides them with fierce beginnings and thus contains potentials for collective action. By differentially joining in and departing from folk dance groups, protesters exercise relationality against an Arendtian notion of isolation, and therefore, their action manifests resistance and resilience. By deciding on how to move; whom to follow, challenge, or hold hands with; and how to calibrate individual pace and energy with the dynamics of the group; as well as how long to move and wait until the next assembly and dispersal, activists navigate individually while also finding a sense of larger "body" of assembly. In their choreopolitical efforts, dancer-activists' "artistic interventions" (Mouffe 2007) in the public space not only disclose dominant political structures and violent maneuvers of the state apparatus, but also contest and defy these forces while fostering solidarity among dissenters.

Hannah Arendt reminds us that "while violence can destroy power, it can never become a substitute for it" ([1958] 1998, 202); and likewise, coercive police strategy could not completely prevent innovative political action. As I have shown, dispersal, in the case of Turkey, is used both as a hegemonic choreography of isolation and as a survival tactic of protesters, who mobilize individual and collective agency by persistently maintaining their connection in support of progressive politics. I have argued that by scattering themselves towards the peripheries of the central space of activism, dissenters re-choreograph a thanatopolitical strategy of dispersal in order to gain power. Dispersed protesters, in constant motion, improvise new forms of interaction-which may or may not be decipherable to the police, as they similarly study the routes, maneuvers, and engagements of resistant bodies in order to anticipate their next movement. Activists also perform an affirmative politics of dispersal by executing folk dance in protests. I discussed questions of temporality and positionality by examining how demonstrators participate in and leave the dance; how long they perform referring to multiple concepts of duration; and how they position themselves in the group based on their own experience and familiarity with the dance form. Protest participants' different motivations and analyses of their own actions demonstrate a wide variety of approaches in the performance of dispersal.

By foregrounding the experience and relationality of diverse individuals, Arendt's notion of politics provides us with a horizon to analyze how grassroots activists from different backgrounds can move together, embracing and building on this variety in experience. At the same time, activists appropriating the choreographic potential of tactics of dispersal propose new ways of making the separation of bodies relational, and thereby undermine the violence of isolation that Arendt describes. Whenever they gather and form moving assemblies, protesters relate to each other in innovative ways and continuously develop resilient choreographies of dissent. 
1 Thanks to Roii Ball, Mika Lior, and Archer Porter as well as the journal editors and anonymous readers for feedback on drafts of this paper.

2 The activists' use of folk dance as a form of protest in contemporary Turkey is analysed in detail in my Ph.D. dissertation (Bayraktar 2019). I am grateful to my research participants who made both the dissertation and this article possible.

${ }^{3}$ In the 2000s, urban transformation projects aimed to bring about physical and demographic upgrading of their respective areas, yet they caused a process of property transfer and displacement of socially and economically marginalized groups (Kuyucu and Ünsal 2010).

${ }^{4}$ Although the movement started against the neoliberal urban policies degrading public spaces and green areas in the city, authoritarian political practice of the government was the immediate object of the discontent (Ertür 2014, Yeğenoğlu 2013, Yörük and Yüksel 2014). Public surveys (KONDA 2014) showed that 51\% of the Gezi protesters participated in a social movement for the first time in their lives, and 49\% decided to join the movement after seeing the police violence against protesters in the park. The protests resonated both in upper-class areas of Istanbul and also in labour class neighbourhoods. The majority of activists were against the top-down production and organization of the space and demanded equal distribution of wealth and civil rights.

5 The research participants' names have been changed to maintain the confidentiality of identities. The interviews were originally conducted in Turkish and translated to English by the author who is solely responsible for mistranslations.

\section{Works Cited}

Agamben, Giorgio. 1998. Homo Sacer: Sovereign Power and Bare Life. Translated by Daniel Heller-Roazen. Stanford, CA: Stanford University Press.

2005. State of Exception. Translated by Kevin Atell. Chicago: University of Chicago Press.

Arendt, Hannah. (1958) 1998. The Human Condition. $2^{\text {nd }}$ edition. Chicago: The University of Chicago Press.

(1958) 1966. The Origins of Totalitarianism. New York: Harcourt, Brace \& World.

2005. The Promise of Politics. New York: Schocken Books.

Batuman, Bülent. 2015. "Everywhere is Taksim": The Politics of Public Space from Nation-Building to Neoliberal Islamism and Beyond." Journal of Urban History (41) 5: 881-907.

https://doi.org/10.1177/0096144214566966

Bayraktar, Sevi. 2019. Demonstrating Dance: Women's Mobilization of Horon as Protest in Turkey. Ph.D. Dissertation. University of California, Los Angeles.

Butler, Judith. 2009. Frames of War: When Is Life Grievable? London and New York: Verso.

_- - 2015. Notes Toward a Performative Theory of Assembly. Cambridge, MA: Harvard University Press. https://doi.org/10.4159/9780674495548

Butler, Judith, and Athena Athanasiou. 2013. Dispossession: Performative in the Political. Malden, MA: Polity.

De Certeau, Michael. 1984. The Practice of Everyday Life. Berkeley: University of California Press.

Diken Online Newspaper. 2015. "Valilik 1 Mayis'I Taksim'de Kutlamak Isteyen Işçilere Beylikdüzü'nü Adres Gösterdi!” April 18. http://www.diken.com.tr/valilik-1-mayisi-taksimde-kutlamak-isteyen-iscilere-beylikduzunu-adresgosterdi/

Ertür, Başak. 2014. "The Gezi Uprising and Particularities of Discontent." Law and Critique 25: 3-7.

Foellmer, Susanne. 2016. "Choreography as a Medium of Protest." Dance Research Journal (48) 3: 58-69. https://doi.org/10.1017/S0149767716000395 
Foster, Susan Leigh. 2003. "Choreographies of Protest." Theatre Journal 55 (3): $395-412$. https://doi.org/10.1353/tj.2003.0111

Foucault, Michel. 2007. Security, Territory, Population, Lectures at the College de France, 1977-1978. Translated by Graham Burchell. Basingstoke: Palgrave Macmillan.

Gerecke, Alana, and Laura Levin. 2018. "Moving Together in an Era of Assembly." Canadian Theatre Review 176: 510. https://doi.org/10.3138/ctr.176.001

Human Rights Watch. 2018. "Turkey: Government Targeting Academics — Dismissals, Prosecutions Create Campus Climate of Fear." May 14. https://www.hrw.org/news/2018/05/14/turkey-government-targeting-academics

Hürriyet Daily News. 2018a. "Istanbul Governor's Office to permit rallies, demonstrations in just nine areas, Taksim Square not included." http://www.hurriyetdailynews.com/istanbul-governors-office-to-permit-ralliesdemonstrations-in-just-nine-areas-taksim-square-not-included-126692

___. 2018b. "Over 18,500 Turkish Public Workers Dismissed with New Emergency State Decree" July 8. http://www.hurriyetdailynews.com/over-18-500-turkish-public-workers-dismissed-with-new-emergencystate-decree-134290

Jestrović, Silvija. 2013. Performance, Space, Utopia: Cities of War, Cities of Exile. Basingstoke: Palgrave MacMillan. https://doi.org/10.1057/9781137291677

KHKadınname. 2017. "KHKadınname Çağrısı" (Women's Letter Manifesto). February 14. https://khkadinname.wordpress.com/2017/02/14/khkadinname-cagrisi-english- francais-فارسى

Kedhar, Anusha. 2014. "Choreography and Gesture Play an Important Role in Protests." The New York Times, December 15. https://www.nytimes.com/roomfordebate/2014/12/15/what-does-the-style-of-a-protestsay-about-a-movement/choreography-and-gesture-play-an-important-role-in-protests

KONDA. 2014. "Gezi Report: Public Perception of the 'Gezi protests' Who were the people at Gezi park?" June 5, 2014. http://konda.com.tr/wpcontent/uploads/ 2017/03/KONDA_Gezi_Report.pdf

Kuyucu, Tuna, and Özlem Ünsal. 2010. "Urban transformation as State-Led Property Transfer: An Analysis of Two Cases of Urban Renewal in Istanbul." Urban Studies 47 (7): 1479-1499.

https://doi.org/10.1177/0042098009353629

Lepecki, André. 2013. "Choreopolice and Choreopolitics: or, The Task of the Dancer." TDR/The Drama Review 57 (4): 13-27. https://doi.org/10.1162/DRAM_a_00300

LGBTI News Turkey. 2016. "Istanbul LGBTI+ Pride Committee Statement: We are Dispersing!" June 24. https://gbtinewsturkey.com/2016/06/24/Istanbul-Igbti-pride-committee-statement-we-are-dispersing/

Mbembe, Achille. 2003. "Necropolitics." Public Culture. 15 (1): 11-40. https://doi.org/10.1215/08992363-15-1-11

Mouffe, Chantal. 2007. "Artistic Activism and Agonistic Spaces." Art and Research 1 (2). http://www.artandresearch.org.uk/v1n2/mouffe.html

Pişkin, Tansu. 2018. "Deferred Prison Sentence of 1 Year, 3 Months for 2 Academics." Bianet.org. December 12. http://m.bianet.org/english/freedom-of-expression/203439-deferred-prison-sentence-of-1-year-3months-for-2-academics

Ruiz, Polyanna. 2017. "Performing Protest: Occupation, Antagonism and Radical Democracy." In Performing Antagonism: Theatre, Performance and Radical Democracy, edited by Tony Fisher and Eve Katsouraki, 131148. Basingstoke, Palgrave Macmillan. https://doi.org/10.1057/978-1-349-95100-0_7

Yeğenoğlu, Meyda. 2013. "Smells Like gezi Spirit: Democratic Sensibilities and Carnivalesque Politics in Turkey." Radical Philosophy 182. https://www.radicalphilosophy.com/commentary/smells-like-gezi-spirit

Yörük, Erdem, and Murat Yüksel. 2014. "Class and Politics in Turkey's Gezi Protests." New Left Review 89: 113-124. 


\section{Biography}

Sevi Bayraktar has earned her Ph.D. in Culture and Performance from the University of California, Los Angeles in 2019. She uses ethnography and choreographic analyses to examine the relationship between dance, politics, and gender. Her dissertation explores how women from diverse grassroots movements deploy folk dance as protest in contemporary Turkey. Sevi completed her B.A. in Political Science and M.A. in Sociology at Boğaziçi University, Istanbul. Her monograph and co-edited volumes published in Turkish and recent writings appeared in the Journal of Dance, Movement, and Spiritualities and Performance Art in the Public Sphere. Sevi is a professional dancer and dance teacher; and her choreography is inspired by dances of Asia Minor, flamenco, whirling traditions, and the Roma dances in a broad geographical context.

(c) 2019 Sevi Bayraktar

(c) (†) ()

Except where otherwise noted, this work is licensed under a Creative Commons AttributionNonCommercial-ShareAlike 4.0 International License. 